\title{
R.D.S. V. HER MAJESTY THE QUEEN: A Case About Home
}

\section{Sherene Razack}

\begin{abstract}
A white police officer arrested a black 15-year-old who had allegedly interfered with the arrest of another youth. The accused was charged with assaulting a police officer, assaulting a police officer with the intention of preventing an arrest, and resisting a police officer in the lawful execution of his duty. The police officer and the accused were the only witnesses and their accounts differed widely. The Judge weighed the evidence and determined that the accused should be acquitted. While delivering her oral reasons, the Judge remarked, in response to a rhetorical question by the Crown, that police officers had been known to mislead the court in the past, that they had been known to overreact particularly with non-white groups, and that would indicate a "state of mind that is questionable." She also stated that her comments were not tied to the police officer testifying before the court. The Crown challenged these comments as raising a reasonable apprehension of bias. After the reasons had been given, and after an appeal to the Nova Scotia Supreme Court (TrialDivision) had been filed by the Crown, the Judge issued supplementary reasons which outlined in greater detail her impressions of the credibility of both witnesses and the context in which her comments were made. The Crown's appeal was allowed and a new trial ordered on the basis that the Judge's remarks gave rise to a reasonable apprehen sion of bias. Th is judgment was upheld by a majority of the Nova Scotia Court of Appeal. At issue here is whether the Judge's comments in her reasons gaverise to a reasonable apprehension of bias.
\end{abstract}

A $\mathrm{trial}$ is a moment of lines to be crossed and not crossed. Describing the O.J. Simpson trial as one such moment, Toni Morrison comments that such trials construct a national narrative, an agreed upon public truth. In the case of O.J., the official story, Morrison contends, is one of racial culpability. The trial teaches us about Blackness as deviance. Mr. Simpson is thrown into the role of standing in for the entire Black race. ${ }^{1}$

The official story has throw $\mathrm{n}$ Mr. Simp son into that representative role. He is not an individual who underwent and was acquitted from a murder trial. He has become the whole race needing correction, incarceration, censoring, silencing; the race that needs its civil rights disassembled; the race that is sign and symbol of domestic violence; the race that has made trial by jury a luxury rather than a right and placed affirmative action legislation in even greater jeopardy. This is the consequence and p u b 1 i function of @ ffitciab stories: to impess tho w ill i $n$ of a dominant culture.

I propose that we read R.D.S. v. Her Majesty the Queen as a similar moment of public education when an official story, an agreed up on public truth, is told. This public truth is also about race. It is the story that race does not matter except under highly specific and limited circumstances. The heroes of this story are innocent, white subjects.

The effectiveness of official stories should not be underestimated, as Morrison also contends. She observes that after the O.J. trial, ${ }^{2}$

(M)any African Americans found themselves intimidated in the workplace, unwilling to voice even minor a spects of a counter-narrative lest they be accused of ... what? showing race preference? It was easier to say nothing or agree.

T. Morrison, "The Official Story: Dead Man Golfing" in

T. Morrison \& C. Brodsky Lacour, eds., Birth of a

Nation 'hood (New York: Pantheon B ooks, 1997) x xviii.

$2 \quad$ Ibid at $\mathrm{xx}$. 
Women were especially intimidated — because to question the story amounte $d$ to approving of or dismissing domestic violence.

April Burie, representing the Congress of Black women, an intervenor in R.D.S., made the same point about the impact of R.D.S. on people of colour. She began her address to the Supreme Court with a ringing statement that this case was really about home and belonging. What does it mean for a Black person, Ms. Burie asked, to live in a place where racism and the legacies of slavery are routinely and energetically denied? At home, people use "the word." The "racism" word. "How transformative is the power of the word," Ms. Burie observed. In places that are not home, its utterance has the power to bring down the full wrath of the justice system, to define who is reasonable and who is not, who is a good judge and who is not, and who belongs and who does not. Conversely, when it is acknowledged, the word 'racism' has the power to make Canada home. It has the pow er to heal. ${ }^{3}$

While I would not in any way claim that R.D.S. had the same kind of massive educational impact on the lives of people of colour as the O.J. trial did, I do want to say that scars nonetheless remain. Anyone of colour who is in a public role (and I count myself in this group), those few of us who are judges, lawyers, professors, teachers, politicians, in short anyone of us working in the corporate, educational, judicial or political elite, knows about the consequences of disputing the official story. We know now, if we didn't before, what happens when we dare to say that race matters. We have been warned. And this, no matter what the outcome of the decision itself, remains the end uring lesson of R.D.S.

It will surprise some that I begin so despondently since the decision itself counts officially as a win. With Justices Lamer, Sopinka and Major dissenting, the rest of the court (six) rendered a majority decision that Justice Sparks, a Black woman, did not exhibit a reasonable apprehension of racial bias. More than this, Justices L'Heureux-Dubé and McLachlin asserted unequivocally that the comments of Judge Sparks reflected "an entirely appropriate rec ognition of the facts in evidence in this case and of the context within which the case arose." Judge Sparks' comments were not, as another member of the Court, Mr. Justice Cory argued, "close to the line," unfortunate or unnecessary. Instead, they were entirely appropriate. So why don't I feel at home? Why is this acknowledgment of the significance of racism by a majority of the Supreme Court still not enough to convey to me, a woman of colour, that the " $R$ " word no longer separates the citizens from the noncitizens?

My unease with the decision in R.D.S. stems from the powerful lessons this case (the processes leading up to the trials as well as the trials thems elves) offers to people of colour about "the line." This is the line we must not cross. It is the line that Justices Lamer, Major and Sopinka all felt Judge Sparks crossed, the line that Cory J. felt she came close to crossing, and the line that Justices L'Heureux-Dubé and McLachlinfelt shedid not cross. This line separates those who think race always matters from those who think it only matters, if at all, under highly limited circumstances involving specific individuals.

In part one, I turn to the Supreme Court decision itself. A commentator on the lower court trials, Richard Devlin, offered what remains a useful analysis for the trial in the Supreme Court. ${ }^{5}$ Professor Devlin advances the notion that the lower courts embraced a formalist position and rejected a realist one. In the case of the formalists, colour blindness holds sway; in the case of the realists, race matters. I suggest that colour blindness as revealed in the Supreme Court's decision was more than simply a commitment to formal equality. I w ould describe colour blindness as a determined making of oneself as innocent, as outside of history, a wilful forgetting. Further, I show that with the exception of L'Heureux-Dubé and McLachlin JJ., the Supreme Court remained faithful to colour blindness. In part two, I consider whether people of colour can use the words of L'Heureux-Dubé and McLachlin J.J. to name the bias of racist white judges. I conclude th at we can but we should take note that colour blindness is always just around the corner, waiting to reinstall innocent white subjects. Finally, I end with a postscript on strategies to make race matter.
R.D.S. v. Queen, \#25063, 1997-03-10. All subsequent references to comments made during the Supreme Court's hearing of the case refer to this source, the videotaped hearing prep ared for television [h ereafter Videotape].

4 R.D.S.v. Her Majesty the Queen and The Women's Legal Education and Action Fund, the NationalOrganization of Immigrant and Visible Minority Women of Canada, the African Canadian Legal Clinic, the Afro-Canadian Caucus of Nova Scotia and the Congress of Black
Women, (1997) 151 D.L.R. (4th) 193 (S.C.C.) at para. 30. R. F. Devlin, “We Can't GoOn Together with Suspicious Minds: Judicial Bias and Racialized Perspective in $R$. v. R.D.S." (1995) 18 Dalhousie L.J. 408. 


\section{PART ONE: MAKING INNOCENT SUBJECTS}

Both lower courts in Nova Scotia agreed with the Crown and in so doing found Judge Sparks to have exhibited bias. Commenting on these decisions, Richard Devlin argued that these lower court decisions represented the triumph of colour blindness over contextualized judging. Devlin distinguished between formalists, who embrace colour blindness and "the assumption ... that each person is an individual and that racial identity (in the sense of skin colour) is an irrelevant consideration, unless its specific relevance can be demonstrated," and realists, for whom race matters and "racialization (in the sense of hierarchical social relations on the basis of race) is still an extremely important social factor and, therefore, that legal decisionmaking should always be sensitive to the possibility that race is a variable," Devlin concluded that the formalists prevailed at the lower courts in R.D.S. ${ }^{6}$

Something different occurred in the Supreme Court. There the realists apparently won the day. That is to say, the majority decision reveals some endorsement for contextualized judging and, thus, for the position that race matters. It is important, however, to consider what colour blindness and contextualized judging mean for this court. Colour blindness, I would contend, as exhibited by the dissenting judges as well as some of those who ultimately decided there was no evidence of bias, is much more than a position advocating formal equality. Rather, it is a determined pursuit of white innocence, marked by considerable anxiety about the real meaning of white and B lack bodies. S ome of this anxiety survives even in the advocates of contextualized judging (L'Heureux -Dubé an d McLachlin JJ.)

The colour blindness approach espoused by Major J. in dissent, and supported by Lamer C.J. and Sopinka $\mathrm{J}$., is the same one articulated by the lower courts: there was no evidence presented at the trial that this particular police officer was motivated by racism. In observing that white police officers sometimes overreact when dealing with non-white youth, Judge Sparks was stereotyping police officers: ${ }^{7}$

In my opinion the comments of the trial judge fall into stereotyping the police officer. She said, among other things, that police officers have been known to mislead the courts, and that police officers overreact whe $n$ dealing $w$ ith

Ibid. at 436 .

R.D.S., supra note 4 at para. 19. non-white groups. She then held, in her evaluation of this particular police officer's evidence, that these factorsled her to "a state of mind right there that is questionable."

It is important to juxtapose the formal logic of this paragraph, that is, that Judge Sparks did not know that this police officer misled the court and overreacted, w ith the comments made by the dissenting judges elsewhere in the decision and during the ora 1 argument in order to appreciate the full nature of the formalist position. "L ife experience is not a substitute for evidence," Major J. argued: "you can't stereotype police officers any more than you can stereotype women, children and minorities. " It is noteworthy, of course, that Judge Sparks is being accused by analogy of a misdemeanor as reprehensible as the stereotyping of society's most disadvantaged groups - women, children and minorities. Relying on the same chain of equivalences (dominant groups $=$ subordinate groups), Lamer C.J. complained during the hearing that the defense appeared to be arguing that the policeman had "some kind of hill to climb to demonstrate he was not racist." 9 Such a burden of proof was clearly unacceptable, the Chief Justice argued, because everyone can claim to be unfairly stereotyped; people of colour hav e no mono poly on racial stereotyping. The Chief justice reminded the defense that he too was a victim of intolerance as a French Canadian. More significantly, asserting that the Chinese were tremendous gamb lers (a statement he later denied by claiming that it was a hypothetical example), ${ }^{10}$ both in his day as a lawyer in Montreal and at the present time, the Chief Justice wond ered if he ought to apply what he knows about the Chinese whenever a Chinese person appeared before him. Once down this "slippery slope" of personal knowledge, he warned, the unthinkable - the stereotyping of people of colour by white judges - will start to happen. ${ }^{11}$ Judge Sparks, by implication, is really leading us straight to racism against people of colour when she suggests that white police officers have been known tooverreactwhen dealing with non-white populations! 
If we are to link the formal logic of colour blindness in the decision to what was said by the dissenting justices during oral arg ument, colour blindn ess begins to look less like formal logic and more like a language to support deeply held beliefs about the inferiority of people of colour. An insistence on formal equality, (a white French Canadian Supreme court judge is the same as a Black youth in Halifax, Nova Scotia in an encounter with white police; Judge Sparks' knowledge of white police officers in Nova Scotia is the same as the Chief Justice's own knowledge of Chinese people's propensity for gambling) looks more like a wilful forgetting of social and historical context, not to mention of subject position. An uneasiness begins to emerge from under the heavy insistence on formal equality, an undertone of emotion, nothing empirically provable, but something that is present none theless in the frequent interruptions, analogies and wild hypotheticals the dissenting justices put to the defense lawyers. Is this the unease that comes from knowing that once race is taken into account, and the stereotypes come tumbling down, what is left is the awesome fact of white supremacy? James Baldwin reminds white people: "If I am not who you think I am, then you are not who you think you are either. And that is the crisis." ${ }^{12}$ Without gambling Chinese and emotional Black women partial to their own people and biased against white police officers, there would be no reasonable and impartial white men.

Not all formalists espoused colour blindn ess with the same degree of insistence as the Chief Justice and Major J. above. Indeed, the line blurs between the formalists and the realists when one considers that those who denied the Crown's appeal, concluding that there was no apprehension of bias, still relied on colour blindness. Justice Cory, (concurring with L'HeureuxDubé and McLachlin J.J.), made a distinction between references to socialcontext based on expert evidence and tendered in a case like Parks (involving jury selection) ${ }^{13}$ and a case like R.D.S., where social context is being used to assist in determining credibility. ${ }^{14}$ He concluded: $:^{15}$

In some circumstances it may be acceptable for a judge to ackn owledge that racism in society might be, for example, the motive for the overreaction of a police officer. This may be necessary in order to refute a submission that invites the judge as trier of fact to presume

12 J. Baldw in, "A T alk to Teachers" (1963) in R. Simonson \& S. Walker, eds., Graywolf Annual Five: Multicultural Literacy (St. Paul: Graywolf Press, 1988) at 8. Cited in L. Lippard, ed., "Introd uction" at 43. Partial R ecall (New York: The New Y ork Press, 1992).

R. v. Parks (1993) 15 O.R. (3d) 324 (Ont. CA).

R.D.S., supra note 4 at para. 127.

Ibid. at para. 132 truthfulness or untruthfulness of a category of witnesses, or to adopt some other form of stereotypical thinking. Yet it would not be acceptable for a judge to go further and suggest that all police officers should therefore not be believed or should be viewed with suspicion where they are dealing with accused persons who are members of a different race. Similarly, it is dangerous for a judge to suggest that a particularperson overreacted because of racism unless there is evidence ad duced to su stain this finding.

If Judge Sparks if off the hook, it largely is because the Crown submitted there was no reason to suspect the police officer might be lying, a submission that itself flies in the face of strict neutrality since it would suggest that police are somehow different from others - an example of unacceptab le group stereotyping.. In spite of his overall assessment that Judge Sparks made her decision based on the evidence before her, Cory J. finds Judge Spark's comments "unfortunate," "troubling," and "unnecessary." Ultimately concluding that the comments of Judge Sparks were "close to the line," Cory J. is not far off from Justices Major, Lam er and Sop inka in regarding race as irrelevant unless its relevance can be very specifically demonstrated. He clearly is equally troubled by the possibility that race might matter.

To L'Heureux-Dubé and McLachlin, JJ., race matters a good deal more than it does to their male colleagues. Instead of finding Judge Sparks' commen ts close to the line as did Cory J., they explicitly announce that the comments "reflect an appropriate recognition of the facts in evidence in this case and of the context within which the case arose - a co ntext know $n$ to Judge Sparks and to any well-informed member of the community." ${ }^{17}$ Relying on Jennifer Nedelsky's argument that judging requires we take the views of marginalized social groups into account, ${ }^{18}$ they proceed to elab orate that a reasonable person engaging in contextualized judging in this instance would have to take into account anti-black racism and the Donald Marshall Inquiry which indicated that racism existed in the N ova Scotia Justice system. ${ }^{19}$ In their reasons, L'Heureux-Dubé and McLachlin, JJ. write unequivocally that "a reasonable person is cognizant of the racial dynamics in the local community." ${ }^{20}$ If this alone served as precedent, racial minorities would have gained a great deal.

Ibid. at para. 153 .

Ibid. at para. 30

J. Nedelsky, "Embodied Diversity and the Challen ges to Law" (1997) 42 McGill L.J. 91.

Supra note 4 at para. 47.

Ibid. at para. 48 . 
If, however, these commen ts are read in the context of the justices assessment of Judge Sparks, a little of their vigour is lost. Justices L'Heureux-Dubé and McLach lin advise us to remember that Judge Sparks delivered an oral judgment and that she probably was an overworked trial judge. ${ }^{21}$ They note that she assessed the testimony $y^{22}$ and the evidence ${ }^{23}$ before her and that her comments were made in response to the Crown's submissions. ${ }^{24}$ They clarify that Judge Sparks found a probable overreaction on the part of the police ${ }^{25}$ but did not conclude that this overreaction was racially inspired ${ }^{26}$ While all of these paragraphs might be taken to weaken the central argument that race matters, in that they sound like the "mitigating circumstances" we ought to take into account to exonerate Judge Sparks, ultimately, their argument does return to a stronger position: ${ }^{27}$

While it seems clear that Judge Sparks did not in fact relate the officer's probable overreaction to the race of the appellant R.D.S., it should be noted that if Judge Sparks had chosen to attribute the behaviour of Constable Steinburg to the racial dynamics of the situation, she would not necessarily have erred. As a member of the community, it was open to her to take into account the well-known presence of racism in that community and to evaluate the evidence as to what occurred against that background.

Agreeing with Freeman J.A., (in his dissenting judgement at the Nova Scotia Court of Appeal), L'Heureux-Dubé and McLachlin, J.J. repeat his words that this case was "racially charged" from the start on account of its location and the race of the key players. ${ }^{28}$ While this does not declare that racism is always a factor in such contexts, it directs us to consider how it might be operating.

\section{PART TWo: CAlling White JUdges TO ACCOUNT}

What, then is the wider application of a direction from the two female justices of the Supreme Court that comes astonishingly close to making Canada home? The

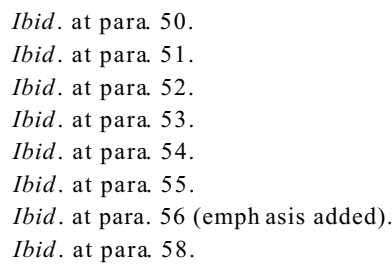

force of colour blindness and what lies behind it gives me pause. It is not easy to forget the wilfulness behind the impulse to treat us all as the same, as though history and context did not matter and the high anxiety that accompanied this performance of strict logic during the trial. Here I want to briefly explore how the reasons of Justices L'Heureux-Dubé and McL achlin might apply in cases of reasonable apprehension of bias when a judge whose impartiality is in question is white, and when what is at issue is his bias against, rather than for, Black men.

On November 15, 1993, a white, male, trial judge began hearing the case of Dudley Laws and Lawrence Motley, both Black men accused of transporting illegal migrants across the Canadian-U.S. border. The trial was a highly pub licized one inv olving a w ell-known Toronto Black activist, Dudley Laws. It had all the ingredients of a racially-charged environment. Mr. Laws was a well known Black activist on the issue of police accountability for the shootings of Black men and the case involved police wiretaps and the possibility that the police had deliberately entrapped Mr. Law s, one of their most vociferous critics. Before the proceedings could even commence, the presiding judge, Judge Whealy, rather unceremoniously demanded that spectators wearing hats take them off. The specific individual(who later was identified as the Imam for prisons) who was asked on the first day to take off his hat or leave, protested that he was wearing a head covering for religious reasons.

The fracas in the court room led to a formal ruling by Judge Whealy two days later. In this ruling he made clear that "a presiding ju dge not on ly has the autho rity but also the duty to oversee the demeanor, solemnity and dignity which must prevail in a superior court of law." ${ }^{29}$ The judge noted that any highly visible groups must be barred from the courtroom. Recognizing that head coverings may be required in some religions, the judge was prepared to grant this right to major, recognized religions but warned that "self-proclaimed and unrecognized forms of religion or cults claiming to be religious" would receive limited protection under the Charter of Rights and Freedoms. ${ }^{30}$ Subsequently, others wearing the head covering were also banned. Since the religion in question was Islam (the world's largest religion), it is not difficult to see why the defense in this case would arg ue that the courtroom barring of Muslim men wearing headdress, all of whom were Black, indicates a reason able apprehe nsion of bias.

\footnotetext{
29 R. v. Laws, [1993] O.J. No. 2844 (22 Nov. 1993) at para. 10 .

$30 \quad$ Ibid. at para. 30 and para. 5.
} 
On January 5, 1995, ruling again on the motion for an order for another judge, Judge Whealy again reiterated his position, denying the motion. ${ }^{31}$ Michael Taylor, one of the men banned from the courtroom filed a complaint against the judge with the Canadian Judicial Council (an interesting parallel to the Halifax Police Chief who complained to the Chief Justice of the Nova Scotia Trial decision about Judge Corinne Sparks). The Council decided that a single ruling by a judge was insufficient evidence to call for Judge Whealy's dismissal. The Canadian Human Rights Commission, with whom Taylor also filed a co mplaint, refused to hear the case because of judicial immunity. Ultimately, Michael Taylor's lawyer went to the Federal Court of Appeal to ask that the Commission be required to hear the case. A lawyer for the Attorney General argued that Whealy's judicialimmunity was absolute and should not be subjected to a discrimination hearing by the commission. He further argued that T aylor could sim ply wait to resolve the issue at the appeal of the Dudley Laws case, a point disputed by Taylor's lawyer on the grounds that the appeal only concerns Law's rights as the accused and not Taylor's rights as a spectator. ${ }^{32}$

What is immediately a difference in the case of Michael Taylor is that it is has not been possible to even air the issue of judicial bias given the great difficulty in getting any single legal body to hear the complaint. This in itself is instructive. Should the issue of Judge Whealy's bias ever be subjected to scrutiny, would it then be possible to argue that in dismissing Islam as a fringe religion, and finding one of its practices incompatible with dignity and decorum in a courtroom, Judge Whealy showed himself to be biased against male, ${ }^{33}$ Black Muslims? Furth er, could it be argued that the judge brought to this case personal knowledge about world religions that was in fact stereotypical and revealing of his bias towards and limited knowledge of the religions practised by racial minorities? Could we point to the racially charged atmosphere (Black/police issues in Toronto) and say that Judge W healy has a du ty to acknowledge the racially charged nature of the case, the more so when he considers his duty to ensure that justice is done and is seen to be done? B arring Mu slim skull caps from the courtroom can hardly indicate his sensitivity to justice being seen to be done. With the words of L'Heureux-Dubé and McLachlin JJ., I believe such arguments can be raised. But two major problems remain. The first, as noted above, is finding a place to

R. v. Laws, [1994] O.J. N o. 33 (5 Janu ary 1994).

Canadian Press, "Make judge go before rights pa nel court told" Toronto Star (8 December 1997) A6.

33 Women wearing headdress were permitted to stay. The reasoning was that most civilized peoples believed that men must take off their hats as a mark of respect. make such arguments. The second is having them used against people of colour who will go on needing to find ways to bring the knowledge of everyday racism into the courtroom. I can imagine many more judges arguing that to notice race is to take us down a slippery slope leading straight to racial stereotyping, which we can interpret either as a threat or a promise.

\section{POSTSCRIPT: RACE IN SCIENTIFIC DRESS}

Throughout the writing of this comment, I repeatedly sought, and failed, to find a way to describe the subject position from which I experienced R.D.S. The personal knowledge I felt I brought to the case, my everyday life as a woman of colour, could not be translated into the langua ge this comment required. It seemed to have no place in academic argument. For instance, I was struck by two details more than any other, and found them immens ely believable an d central, yet I could only weave them into the comment in a postscript. First, R.D.S. is a young, Black man and a cousin of the youth, N.R., who was being arrested by the white officer. In his version of events, he was trying to get the details of the arrest in order to go and tell N.R.'s mother what was happening. A woman, in the crowd of mostly young people under twelve that gathered, attempted to get the phone number of R.D.S. in order to tell his mother what was happening, but the police officer held R.D.S. in a choke hold and he could not respond. In the end, the first youth being arrested, N.R., gave the woman the pho ne number. ${ }^{34}$ Second, the police officer in this case complained to his union and to the police chief about Judge Spark's comments. The Halifax Police Chief then publicly complained to the Chief Family Court Judge. A local newspaper was contacted. The newspaper sought access to the tapes of the transcript but Judge Sparks refused to grantaccess on the grounds that the transcripts were protected under the Young Offenders Act. ${ }^{35}$ The Crown pursued its appeal on the basis of apprehension of bias with wh at appeared to be unseemly vigour. ${ }^{36}$

Taken all together, these tw o aspects of R.D.S. (the behaviour of the Black people in the story and the behaviour of the white people in decision-making roles) push many buttons for me, as I imagine they do for other people of colour. The youth's story about trying to get a message home is entirely familiar. This act of communal solidarity underscores that people of colour must look out for each other in a racially hostile world, and it

R.D.S., supra note 4 at para. 67.
Devlin, supra note 5 at 411.

Ibid. at 429 . 
specifically recalls the need to have community strategies for dealing with racist police who are so often beyond accountability. ${ }^{37}$ The mach inery that swung into action against Judge Sparks for calling attention to the operation of racism - the med ia, the judiciary, the civ il service - is also all too familiar. Yet something makes it difficult for the fully contextualized, historical meaning of these features of life in a racist commu nity to enter the courtroom as things we know to be relevant to the case. The same 'something' makes it difficult for me to argue that they must enter this article as scholarly and not personal knowledge and must help us to read the decision. Having been through the exercise of reviewing both the videotape of the appeal hearing and the written reasons, I wondered what would actually facilitate the entry of everyday and elite racism as facts in the courtroom. Could we, for instance call upon the studies of everyday ${ }^{38}$ and elite ${ }^{39}$ racism to support the credibility of the story of R.D.S. that he was only trying to get a message home? Could we use these studies to show how quickly and efficiently the elites swung in to action to call Judge Sparks to account, a showing of white group consensus? How many more Marshall Inquiries and commissions on systemic racism will suffice? Can we draw on psychologies of prejudice, as American litigators have done, to argue that white stereotyping of Blacks is near inevitable in a racist society? ${ }^{40}$ I think we can, but not without considerable opposition. It is clear that the ideas that give colour blindness its force, ideas of innocent white subjects without histories or present day privilege, block the naming of racism at a deep emotional level. I cannot easily forget the demeanor of several members of the Supreme Court as they pushed and pulled at whatever argument they were offered to make it fit into the small space of colour blindness. Dressing race up in scientific garb seems a weak strategy, at best, in the face of such denial. The double

37 While writing this case comment, the Toron to Star ran a three part series detailing cases where the police assaulted mostly poor people and people of colour and faced no disciplinary measures. See J. D uncan son \& J. Rank in, "Above the Law" Toronto Star (30 November 1997) A1, A14. As well, Bill 105, the Ontario Police Services Amen dments Act was passed which abolished the Police Complaints Commission and any other avenue of complaint to an external, civilian authority about police practices. R. Dimanno, "New Era for complaints against police" Toronto Star (8 December 1997) E1.

38 P. Essed, Understanding Everyday Racism (Newbury Park, C a.: Sag e Pub lication s, 1993).

39 T. van Dijk, Elite Racism (New bury Park, Ca.: Sage Publications, 1993).

40 C. Kwe i Yung Lee, "Race and Self-Defense: Toward A Normative Conception of Reasonableness" (1996) 81 Minnesota L.R. at 462. Richard Devlin also discusses the sociological and psychological research that would support the notion that race is freque ntly con flated $w$ ith crimin ality. Se e Dev lin, supra note 5 at 432. legacy of R.D.S. for me is that while it offers a small ray of light that race does count, it also con firmed that to make it count more often, we will need something more than a scientific study or two on the operation of racism in Canadian society.

\section{Sherene Razack}

Department of Sociology and Equity Studies, The Ontario Institute for Studies in Education of the University of Toronto. 